\title{
Diversification as a means to improve household food security in Bangladesh
}

\section{Rehan, Feroze}

2021

Rehan , F , Sumelius , J \& Bäckman , S T 2021, ' Diversification as a means to improve household food security in Bangladesh ' , Journal of Developing Areas , vol. 55 , no. 2 . https://doi.org/10.1353/jda.2

http://hdl.handle.net/10138/322396

https://doi.org/10.1353/jda.2021.0030

Downloaded from Helda, University of Helsinki institutional repository.

This is an electronic reprint of the original article.

This reprint may differ from the original in pagination and typographic detail.

Please cite the original version. 


\title{
DIVERSIFICATION AS A MEANS TO IMPROVE HOUSEHOLD FOOD SECURITY IN BANGLADESH
}

\author{
Sheikh Feroze Rehan \\ John Sumelius \\ Stefan Bäckman \\ University of Helsinki, Finland
}

\begin{abstract}
Food security becomes an issue for concern and possible policy response when it points to nutritional deficiencies and access to insufficient food in many developing countries. Over the years, the prime focus has been on self-sufficiency in major cereal production and energy availability for food security in these areas. Diversification in farm production could play a part in improving household nutritional well-being through enhancing economic access to food and increasing the opportunity to consume own production. The aim of this paper is to bridge the research gap by providing quantitative evidence on the impact of farm diversity on household food security, highlighting the nutritional dimension in Bangladesh where rice is considered the major cereal item. In doing this, the authors compare farm households that are very specialized in rice cultivation with more diversified farm households using two different measures of dietary diversity. In addition, two other measures of farm diversificationSimpson's Index of Diversity along with a crop-livestock count variable-have been used in the analysis. The empirical results presented here are based on cross-sectional data collected through a multistage random sampling of 260 farm households in central, northern, and southwestern regions of Bangladesh. The results confirm that farm diversification has a positive and significant influence on food diversity and it therefore improves household food security. Diversification through shifting out of cereal cultivation particularly rice production is found to be an effective and noteworthy approach to enhance food diversity in Bangladesh. In addition, household food diversity is influenced by higher education level, better market access, household size, production per capita, non-farm income diversification, and land size. The study suggests that investment in education and development of infrastructure for better market access will help to boost dietary diversity in Bangladesh. The key policy implication is that farm diversity needs to be encouraged as an important strategy to increase consumption of a varied diet and enhance household food security.
\end{abstract}

JEL Classification: 013, Q12,

Keywords: Food security, farm diversification, dietary diversity, Bangladesh

Corresponding Author's Email Address: john.sumelius@helsinki.fi

INTRODUCTION

Food security has been at the focus of development policies and academic interest for many decades. Approximately one out of every nine people in the world are undernourished, $98 \%$ of whom live in the developing world (FAO et al., 2015, 2018). Diversification may be a workable strategy to pull this group of people out of food insecurity through improving economic access to food by reducing income variability or by increasing income through higher return opportunities. Besides, diversified production of crops, animal products, fish, and other products offers the opportunity to farmers to consume their own production. It may ensure a secure supply of food during natural and/or market shocks. This research examines the 
relationship between diversification and food security with an aim to improve food security at the household level in developing countries.

Food security is achieved when all people, at all times, have constant access to sufficient, safe, and nutritious food that meets the dietary needs and food preferences required for an active and healthy life (FAO, 1996). Food security consists of four dimensions, namely food availability, food stability, food utilization, and access to food (Ashby et al., 2016). In developing countries, food security is a major concern because a large share of the population suffers from nutritional deficiency. The policy to grow staple grain crops has been acknowledged but dietary diversity has received little attention. Availability is, however, not enough-people need to consume nutritionally adequate food. In this paper, an attempt has been made to formulate strategic options for food security, highlighting the nutritional dimension. Here, diversified farms are involved in non-farming activities (Rønning and Kolvereid, 2006; Minot et al., 2006; Carter et al., 2004). Diversification also refers to moving out of rice monoculture to various farming activities such as crop production and non-crop food production such as livestock, poultry, and fishing. Diversity in the production of crops, animal products, fish, and other products could be the correct strategy to ensure a more nutritionally adequate and varied diet as this would enable households to directly consume their own diversified production. This is in contrast to the standard idea of specialization and economies of size since most farmers in Bangladesh do not have the possibility to achieve an optimal production scale.

Amartya Sen's (1981) thinking on entitlements related to food security is widely accepted. The theory implies that the availability of food is important but access to food is a greater constraint. This indicates that sufficient income generation is vital in order to be able to acquire the food that the household requires. Incremental earnings and a reduction in income variability from diversification have the potential to secure access to sufficient food and thus improve household food security. Diversification allows a smooth flow of income by diminishing income fluctuations. Agricultural insurance schemes have been largely unsuccessful in many developing countries (Cervantes-Godoy et al., 2013). Thus, highly specialized farmers are unprotected from risk because of variations in prices and/or yields of specific commodities. Diversified farms spread the risk over two or more farming activities, and they offer increased protection against natural and/or market uncertainties (Mishra et al., 2004).

In addition, the strategy contributes to enhancing farm income. Hansson et al. (2010) pointed out that diversified farms include non-conventional agricultural production activities along with conventional farming. Diversification into higher marketable non-cereal and non-crop 
items - in addition to, or as a substitute for, cereals - results in higher income (Joshi et al., 2007). Empirical evidence has confirmed that moving out of cereal monoculture into suitable crops and non-crops agriculture is financially profitable for the farmers (see Barghouti et al., 2004; Van den Berg et al., 2007). Noticeably, a growing middle class has diversified its diet away from staple cereals to animal products, fruits, and vegetables in developing countries (Warr, 2014). This trend in consumption provides an opportunity for diversification and it can produce higher returns for farm households. It is evident that the rapidly shrinking agricultural lands around the world are big barriers to food security and farmer income. Weinberger and Lumpkin (2007) argued that the production of non-cereal crops such as fruits and vegetables has a comparative advantage over staple crops if the arable land is scarce. So, the approach suits the current situation of many developing countries and may contribute to improving the food security status.

The goals of the research were twofold being first to analyze the role of diversification in household food security highlighting the nutritional dimension, and second, to identify the factors that influence food security.

\section{SIGNIFICANCE OF THE STUDY}

A central policy issue for food-insecure regions is how best to respond to food insecurity. It is significant to note that current studies on diversification reveal inconclusive evidence and further research on the topic is further recommended. Some studies reported positive significant links between farm and diet diversity (see Jones et al., 2014); on the other hand, farm diversity strategy has been identified as not the most efficient way to increase dietary diversity (see Koppmair et al., 2017). Moreover, available studies focus mostly on sub-Saharan Africa and emphasize the importance of further studies in different contexts (Jones, 2017). Islam et al. (2018) argued that to understand the connection of farm diversity and diet outcomes properly, more research is required from the Asian perspective as the strength of associations varies with context. The study contributes to bridging the research gap by providing quantitative evidence on the impact of diversity in agriculture on household food security in the Asian context and specifically from the perspective of Bangladesh.

Traditionally, farms in Asian countries have been associated with the production of a few crops such as rice and wheat, with a focus on achieving sufficiency in production (Bamji 2007; Ahmad and Isvilanonda, 2003). Farm diversification from the Southeast Asian perspective can be characterized as a gradual movement out of rice growing into more diversified market- 
oriented production. Realizing the benefit of the strategy, the Seventh Five Year Plan FY2016FY2020 (General Economics Division and Planning Commission, 2015) stresses spreading the production of non-cereal crops and non-crop agricultural products among Bangladeshi farm households. Considering the relevance and importance of this, in the context of Bangladesh, the present study captures the effect of moving out of rice monoculture on dietary diversity through the agricultural diversification index (ADI). In this case, the ADI is considered to be one of the measures of farm diversity, and the influence of ADI on food diversification has been investigated. To the best of our knowledge this is a vital contribution to a thin body of literature on this issue as none of the previous studies have taken into account such a dimension of farm diversification and analyzed the effect of shifting out of rice monoculture to various farming activities such as crop and non-crop food production on dietary diversity.

The rest of the paper is organized as follows. Section 2 provides a literature review. Section 3 describes the data sources and methods used in this study. In Section 4, descriptive statistics are outlined, followed by the data sources and methods. The results are discussed in Section 5, and the paper ends with conclusions.

\section{LITERATURE REVIEW}

Shifting out of rice production and engaging in non-rice crop cultivations and/or non-crop agriculture such as livestock, poultry, and fisheries can be considered farm diversification in the context of Bangladeshi agriculture that can benefit farming households in two ways: 1) by increasing income and reducing income variability, and/or 2) through diversity in food consumption (Rehan et al., 2017). Production orientation of farms influences food diversification of households. Market-oriented farm households place more emphasis on cash crop cultivation and are less reliant on subsistence production. They rely more on purchasing food for consumption through income generated from selling the output. Jones et al. (2014) used nationally representative cross-sectional data from Malawi to analyze varieties of production utilizing a crop-livestock count variable and Simpson's Index of Diversity. The authors found that farm production diversity is associated with greater household dietary diversity. They confirmed that households whose diet relied less on subsistence production had a more diverse diet. Market-oriented production yields nutritional benefits as income from production is transferred into nutrient-dense, diverse foods. In view of its importance, Pingali (2015) suggested that governments in many sub-Saharan Africa and South Asian countries should emphasize a holistic view of food security to ensure a variety of nutrients and foods 
instead of the current policy to become self-sufficient in only primary staple grains. However, factors such as investment in roads, transport, and a market information system is necessary to allow farmers to grow market-oriented products.

Sibhatu et al. (2015) found that diversification out of cereal production and a focus only on cash crops was linked to greater food diversity. They examined the relationship in Indonesia and identified that dietary gains were realized through enhanced income and the purchase of more diverse foods. Most of the farmers in their sample grew only rubber and the farmers that diversified often adopted palm oil as an additional cash crop. Thus, diversification results in higher household income and food diversity through the purchase of more diverse foods.

Evidence also reveals that the strategy to cultivate cereals together with non-cereal crops such as vegetables helps the farm households to consume a varied, healthier diet both in quantity and quality. Rajendran et al. (2017) used Simpson's Index and multiple regression analysis of data obtained from 300 smallholder farmers in Tanzania. Their results showed that an increase in crop diversity and crop income positively influences household dietary diversity. The study found that diversification shifted toward market-oriented high value crops offers a higher price and accumulates higher revenues from the market. The authors stressed improving economic access to a variety of foods through increased crop diversification that focuses on the integration of nutrient enriched crop foods with staple crops.

Some of the empirical studies point to agricultural diversification among farms benefiting diets via a source of secured food where the households prefer to rely less on market purchased foods. In Mexico, for example, Dewey (1981) reported that higher crop diversity positively influenced the number of food items consumed from own production and was linked to less reliance on market purchased foods in areas where wages are low and food prices very high. The author observed a tendency to shift for economic benefit to non-cereal crops from selfsufficiency in subsistence crop production. Moreover, production of non-cereal crops could more easily be incorporated into a combination of wage labor and work on the family plot than the production of subsistence crops. Johns (2017) further explained that less food purchasing and a higher consumption of own production function as coping mechanisms against food insecurity.

In the recent past, Koppmair et al. (2017) argued that factors such as access to market, production inputs, and technologies are more important for dietary diversity than production orientation. The authors studied the relationship at the household and individual level in 
Malawi where the dietary diversity score was measured from 24-hour recall data. It was noticeable that they found very similar results for household and individual level dietary data.

The previous papers investigated the relationship between, but not the effect of, farm diversification and dietary diversity considering diversification of production beyond cereals, especially rice production. The literature shows that diversification into high value non-cereal and non-crop items results in higher income and offers a comparative advantage over staple crops. Diversification of production beyond rice, which is the main cereal, contributes to rapid income growth, minimizes agricultural risk, and improves the nutrient balance of soil (Miah and Haque, 2013). Considering its usefulness, governments have emphasized the promotion of diversification of production beyond rice. Thus, taking into account the priority and appropriateness, an effort has been made in this paper to address this issue in particular.

\section{STUDY AREAS AND DATA COLLECTION}

Data which were used in this article are from a comprehensive survey of farm households in central, northern, and southwestern regions of Bangladesh conducted from June to September, 2014. These three regions cover both wet agroecological and dry agroecological zones of Bangladesh. The choice of Bangladesh as a case study is based on the fact that the socioeconomic conditions of the country typically represent the traits of a developing country. Ensuring food security for all, especially from a nutritional point of view, is one of the main challenges that Bangladesh faces today. Like many other developing countries, over the years food security has often been equated with achieving self-sufficiency in cereal production and energy availability. Recent agricultural development policies have begun to emphasize diversification assuming that agricultural diversity will contribute to dealing with many issues including nutritional food security. This research provides empirical evidence to validate this transition by offering insights into the agricultural diversification and food security relationship. A multistage random sampling method was used to select 260 farm households from three regions. The data for this research were collected through questionnaires and personal interviews.

\section{THEORETICAL MODEL}

The agricultural household model (AHM) appears to be an appropriate theoretical framework for the semi-subsistence farm households like those in the study region. AHMs integrate production and consumption decisions into rural semi-commercial conditions (Singh et al., 1986). These models consider the interrelationship between production, income, and 
consumption within the household (Elhorst, 1994). In rural semi-commercial conditions, where some inputs are purchased and some outputs sold, production decisions are made with reference to market prices. Maximization of utility yields the following form of food demand equation according to Feleke et al. (2005):

$F_{k}=F_{k}\left[P_{i}, P_{m}, w, Y^{*}\left(w, A^{0}, K^{0}, N\right), D_{h}\right]$

where $P_{i}$ and $P_{m}$ represent the price of goods, $w$ stands for wages, $A^{0}$ stands for quantity of land, and $K^{0}$ represents capital. In addition, $N$ stands for non-farm income, and $D_{h}$ represents household characteristics.

Demand for diversified food is influenced by income rises (Yu and Abler, 2009; Zhou et al., 2014), farm production (Rashid et al., 2011; Kirsten et al., 1998), and better infrastructure (Rahman, 2015). Income growth provides household consumers with more options to choose a quality diet and thus affects the demand for food diversification. Besides, diversified production stimulates diversified food consumption through offering the opportunity and freedom to consume various food items. In addition, better infrastructure influences dietary diversity positively as access to market, storage facilities, etc. enable nearby farms to sell various agricultural products at the best price and ensure the availability of a variety of foods for household consumption. The Feleke et al. (2005) equation was chosen for this study as it includes these different factors in a single framework.

\section{ECONOMETRIC MODEL}

In this paper, the Food Consumption Score (FCS) and Household Dietary Diversity Score (HDDS) have been used as dependent variables to analyze food diversity and household food security. Since these were categorical ordered variables, the following model was used in this paper after Greene (2012):

$y^{*}=x^{\prime} \beta+\varepsilon$

$y^{*}$ is unobserved. What we do observe is

$y=0$ if $y^{*} \leq 0$

$y=1$ if $0<y^{*} \leq u_{1}$

$y=2$ if $u_{1}<y^{*} \leq u_{2}$ 
$y=J$ if $u_{J-1} \leq y^{*}$

Here, $\mathrm{y}=$ FCS / HDDS.

The $u$ s are unknown parameters to be estimated with $\beta$.

The following independent variables were used for the models:

$x 1=$ Farm diversity

$x 2=$ Education level of household head in years

$x 3=$ Wealth of the household

$x 4=$ Household size

$x 5=$ Production per capita

$x 6=$ Access to market in $\mathrm{km}$

$x 7=$ Land size

$x 8=$ Non-agricultural income

$x 9=$ Northern region dummy (dummy: yes $=1$, otherwise $=0)$

$x 10=$ Central region dummy (dummy: yes $=1$, otherwise $=0$ ).

\section{VARIABLE MEASUREMENT}

\section{Measurement of dietary diversity}

Diets with a greater variety of food or food groups are associated with greater energy and nutrient intake (Hoddinott and Yohannes, 2002; Kant 2004). Drescher and Goddard (2008) mentioned that food diversity indicators are food-based dietary quality measures. Dietary diversity accesses the extent to which nutritional needs are being met (Jones et al., 2014) and it is associated with energy availability (Ruel, 2003). Thus, dietary diversity at the household level can be considered an indicator of food security (Swindale and Punam, 2005; WFP, 2009; Kennedy et al., 2011).

Dietary diversity was measured in two ways. First, an HDDS was constructed based on the 12 food groups consumed by each household in the previous 24 hours. Second, dietary diversity was indicated through calculation of the household FCS. The FCS is a frequency weighted diet diversity score based on eight food groups consumed by a household during the last 7 days. The consumption frequency of each food group was multiplied by an assigned weight that is 
based on its nutrient content, and those values were then summed to obtain the FCS. This score is then converted into four level categorical variables using standard guidelines provided by the World Food Programme (WFP, 2009). The four categories are: 1) poor dietary diversity if the FCS is less than 29,2) borderline dietary diversity if the FCS is within the range of 29-42, 3 ) acceptable dietary diversity if the FCS is within the range of 43-52,4) high dietary diversity if the FCS is greater than 52 .

The HDDS and FCS are both categorical ordered dependent variables. Therefore, the ordered probit model was used for the econometric analysis. A similar approach was adopted in the previous studies. The terms "dietary diversity" and "food diversity" have been used interchangeably in this paper.

\section{Measures of farm diversity}

Three different measures of farm diversity have been used in this analysis. First, a croplivestock count variable was created that sums the total number of different crops cultivated and the number of different animal species reared by the households. This is a simple unweighted count measure and has been used in a number of studies (Islam et al., 2018; Sibhatu et al., 2015).

Second, Simpson's Index of Diversity (SID) was used to measure farm diversity, which is defined as:

$S I D=1-\sum_{i} P_{i}^{2}$

where $\mathrm{P}_{\mathrm{i}}$ is the proportion of agricultural income generated from source $i$, which includes crop production and non-crop food production such as livestock, poultry, and fishing. The index is created by calculating each different agricultural source of income weighted by its contribution to the total farm income.

Third, this paper recognizes that diversification in agriculture involves the production of alternative crops and also the rearing of animals on the farm (Meert et al., 2005). In Bangladesh, a major rice producing nation, diversification took the form of a move out of rice monoculture into suitable crop and non-crop agriculture. The ADI takes the value " 0 " when the farm is only producing rice; otherwise the value is " 1 ". In this case, diversified farm households are those farms that are engaging in non-rice crop and/or non-crop agriculture such as livestock, poultry, and fisheries, in addition to, or as a direct substitute for, rice cultivation. On the other hand, 
non-diversified farms are defined as those that only produce rice. The terms "agricultural diversification" and "farm diversification" have been used interchangeably in this paper.

\section{Measurement of other variables}

Some other variables were included in the model that could potentially influence household food security. The wealth status of the household was determined by valuable assets or household possessions such as livestock, farm equipment, radios, and bicycles. Nonagricultural income included wage income along with income earned from non-farm activities such as the owner's non-farm enterprises. Access to the market was assessed by the distance from the household to the nearest market in kilometers. The minimum distance from the household to the nearest market was synonymous with higher access to the market. Production was calculated by the market value of all the agricultural products produced by the farm.

\section{DESCRIPTIVE STATISTICS}

The key characteristics of non-diversified and diversified farms are given in Table 1. It is important to note that on the basis of descriptive statistics there was a significant difference between non-diversified and diversified farms in terms of dietary diversity indicators such as the HDDS and FCS. The diversified farms had a higher level of food diversification than nondiversified farms. In terms of wealth, diversified farm households seemed to be wealthier compared with non-diversified farms. It also appeared that diversified farms generated more production per capita than non-diversified farms.

\section{TABLE 1: KEY CHARACTERISTICS OF NON-DIVERSIFIED AND DIVERSIFIED FARMS}

\begin{tabular}{llllll} 
Variables & \multicolumn{2}{l}{$\begin{array}{l}\text { Non-diversified } \\
\text { farms }(\mathbf{n = 1 0 9 )}\end{array}$} & $\begin{array}{l}\text { Diversified farms } \\
(\mathbf{n = 1 5 1 )}\end{array}$ & $\begin{array}{l}\text { T-test } \\
\text { significance }\end{array}$ \\
& $\begin{array}{l}\text { Mean } \\
\text { value }\end{array}$ & SD & $\begin{array}{l}\text { Mean } \\
\text { value }\end{array}$ & SD & \\
& 5.75 & 4.34 & 5.17 & 3.75 & 1.11 \\
$\begin{array}{l}\text { Education level of } \\
\text { household head (years) }\end{array}$ & & & & & \\
$\begin{array}{l}\text { Wealth (Bangladeshi taka, } \\
\text { BDT) }\end{array}$ & 2.37 & 2.00 & 4.73 & 5.33 & $-4.96 * * *$ \\
$\begin{array}{l}\text { Household size (person) } \\
\text { Production per capita }\end{array}$ & 4.86 & 1.87 & 5.03 & 1.81 & -0.76 \\
(BDT) & 2.38 & 2.19 & 5.19 & 4.84 & $-6.27^{* * *}$
\end{tabular}




$\begin{array}{llllll}\text { Access to market }(\mathrm{km}) & 3.41 & 2.38 & 3.14 & 2.07 & 0.99 \\ \text { Land size (decimal) } & 131.27 & 95.87 & 142.89 & 112.21 & -0.89 \\ \begin{array}{l}\text { Non-agricultural income } \\ \text { (BDT) }\end{array} & 8.57 & 8.31 & 8.23 & 8.96 & 0.32 \\ \begin{array}{l}\text { Northern region of } \\ \text { Bangladesh (yes = } \\ \text { otherwise =0) }\end{array} & 0.44 & 0.49 & 0.27 & 0.44 & 2.69^{* * *} \\ \begin{array}{l}\text { Central region of } \\ \text { Bangladesh (yes = 1, }\end{array} & 0.32 & 0.46 & 0.36 & 0.48 & -0.72 \\ \text { otherwise =0) } & & & & & \\ \begin{array}{l}\text { FCS } \\ \text { HDDS }\end{array} & 65.76 & 15.56 & 73.60 & 15.00 & -4.06^{* * *} \\ \begin{array}{l}\text { Simpson's Index } \\ \text { Crop and livestock }\end{array} & 0.04 & 1.36 & 6.74 & 1.52 & -3.90^{* * *} \\ \text { number } & 11.86 & 9.07 & 13.84 & 11.39 & -1.56 \\ \end{array}$

Note: $* * *$ indicates significance at the $1 \%(\mathrm{P}<0.01)$ level.

FCS $=$ Food Consumption Score; HDDS = Household Dietary Diversity Score; SD = standard deviation.

Tables 2 and 3 show the positive impact of farm diversification on the FCS and HDDS by food group, respectively.

TABLE 2: FCS IN THE PREVIOUS 7 DAYS BY FOOD GROUP

$\begin{array}{llll}\text { Major food } & \text { Non-diversified farms } & \text { Diversified farms } & \text { T-test } \\ \text { groups } & (n=109) & (n=151) & \text { significance }\end{array}$

$\begin{array}{llllll} & \text { Mean value } & \text { SD } & \text { Mean value } & \text { SD } & \\ \text { Staples } & 13.81 & 0.57 & 13.54 & 0.89 & 2.90 * * * \\ \text { Pulses } & 4.01 & 2.92 & 5.42 & 3.64 & -3.44 * * * \\ \text { Vegetables } & 3.55 & 1.61 & 3.83 & 1.75 & -1.30 \\ \text { Fruits } & 0.24 & 0.84 & 0.54 & 1.18 & -2.34 * * \\ \text { Meat and fish } & 14.82 & 6.23 & 17.51 & 5.31 & -3.64 * * * \\ \text { Milk } & 11.04 & 10.18 & 13.88 & 10.18 & -2.21 * *\end{array}$

Note: $* * *$ and $* *$ indicate significance at the $1 \%(\mathrm{P}<0.01)$ and $5 \%(\mathrm{P}<0.05)$ level, respectively. FCS $=$ Food Consumption Score; $\mathrm{SD}=$ standard deviation . 
In Table 2, on average, diversified farms showed significantly higher consumption of pulses, fruits, meat, fish, and milk food groups compared with non-diversified farms in the previous 7 days.

Similarly, according to Table 3, a higher level of food items was consumed from groups such as pulses, vegetables, meat, fish, and milk by households of diversified farms than nondiversified farms in the previous 24 hours.

\section{TABLE 3: HDDS IN THE PREVIOUS 24 HOURS BY FOOD GROUP}

\begin{tabular}{|c|c|c|c|c|c|}
\hline \multirow[t]{2}{*}{$\begin{array}{l}\text { Major food } \\
\text { groups }\end{array}$} & \multicolumn{2}{|c|}{$\begin{array}{l}\text { Non-diversified farms } \\
(n=109)\end{array}$} & \multicolumn{2}{|c|}{ Diversified farms $(n=151)$} & \multirow[t]{2}{*}{$\begin{array}{l}\text { T-test } \\
\text { significan }\end{array}$} \\
\hline & Mean value & SD & Mean value & SD & \\
\hline Staples & 1.00 & 0.00 & 0.88 & 0.31 & $4.36 * * *$ \\
\hline Pulses & 0.35 & 0.48 & 0.64 & 0.48 & $-4.70 * * *$ \\
\hline Vegetables & 0.62 & 0.48 & 0.86 & 0.34 & $-4.49 * * *$ \\
\hline Fruits & 0.43 & 0.49 & 0.42 & 0.49 & 0.11 \\
\hline Meat and fish & 0.77 & 0.42 & 0.89 & 0.30 & $-2.59 * * *$ \\
\hline Milk & 0.43 & 0.49 & 0.58 & 0.49 & $-2.42 * *$ \\
\hline
\end{tabular}

Note: $* * * * *$, and $*$ indicate significance at the $1 \%(\mathrm{P}<0.01), 5 \%(\mathrm{P}<0.05)$, and $10 \%(\mathrm{P}<0.10)$ levels. HDDS $=$ Household Dietary Diversity Score; $\mathrm{SD}=$ standard deviation .

\section{RESULTS AND DISCUSSION}

In this section, the study analyzes the role of diversification in food diversity. Influencing factors which facilitate diversified household food consumption have also been identified. The results are presented in Table 4.

\section{Role of farm diversity in food diversity}

All measures of farm diversity are significantly positively related to dietary diversity except for the relationship between Simpson's Index and the HDDS. This empirically implies that households that diversify their farm production activities will tend to increase their dietary diversity. The crop and livestock count measures were significantly positively associated with both HDDS and FCS. One additional crop or livestock species leads to a $1.7 \%$ and $2.4 \%$ increase in the HDDS and FCS, respectively. Simpson's Index was similarly positively related to FCS but was not associated with the HDDS. 
TABLE 4: DETERMINANTS OF HOUSEHOLD DIETARY DIVERSITY

Independent variables
Farm diversity measure

\begin{tabular}{|c|c|c|c|c|c|c|}
\hline & \multicolumn{2}{|c|}{$\begin{array}{l}\text { Crop and livestock } \\
\text { count }\end{array}$} & \multicolumn{2}{|c|}{ Simpson's Index } & \multicolumn{2}{|c|}{$\begin{array}{l}\text { Agricultural } \\
\text { diversification index }\end{array}$} \\
\hline & HDDS & FCS & HDDS & FCS & HDDS & FCS \\
\hline Farm diversity & $\begin{array}{l}0.016 \\
(2.22) * *\end{array}$ & $\begin{array}{l}0.023 \\
(2.35) * *\end{array}$ & $\begin{array}{l}0.426 \\
(1.25)\end{array}$ & $\begin{array}{l}0.785 \\
(1.97) * *\end{array}$ & $\begin{array}{l}0.355 \\
(2.35) * *\end{array}$ & $\begin{array}{l}0.316 \\
(1.80) *\end{array}$ \\
\hline $\begin{array}{l}\text { Education level } \\
\text { of household } \\
\text { head }\end{array}$ & $\begin{array}{l}0.049 \\
(2.84) * * *\end{array}$ & $\begin{array}{l}0.042 \\
(2.08) * *\end{array}$ & $\begin{array}{l}0.055 \\
(3.21) * * *\end{array}$ & $\begin{array}{l}.0483 \\
(2.38) * *\end{array}$ & $\begin{array}{l}0.058 \\
(3.35) * * *\end{array}$ & $\begin{array}{l}0.049 \\
(2.44) * *\end{array}$ \\
\hline Wealth & $\begin{array}{l}0.056 \\
(3.42) * * *\end{array}$ & $\begin{array}{l}0.114 \\
(3.50) * * *\end{array}$ & $\begin{array}{l}0.054 \\
(3.19) * * *\end{array}$ & $\begin{array}{l}0.110 \\
(3.27) * * *\end{array}$ & $\begin{array}{l}0.050 \\
(3.00) * * *\end{array}$ & $\begin{array}{l}0.114 \\
(3.42) * * *\end{array}$ \\
\hline Household size & $\begin{array}{l}0.068 \\
(1.74) *\end{array}$ & $\begin{array}{l}0.090 \\
(1.76) *\end{array}$ & $\begin{array}{l}0.078 \\
(1.99) * *\end{array}$ & $\begin{array}{l}0.113 \\
(2.19) * *\end{array}$ & $\begin{array}{l}0.060 \\
(1.52)\end{array}$ & $\begin{array}{l}0.085 \\
(1.64)\end{array}$ \\
\hline $\begin{array}{l}\text { Production per } \\
\text { capita }\end{array}$ & $\begin{array}{l}0.052 \\
(2.55) * *\end{array}$ & $\begin{array}{l}0.057 \\
(2.21) * *\end{array}$ & $\begin{array}{l}0.058 \\
(2.87) * * *\end{array}$ & $\begin{array}{l}0.067 \\
(2.61) * * *\end{array}$ & $\begin{array}{l}0.040 \\
(1.84) *\end{array}$ & $\begin{array}{l}0.047 \\
(1.71) *\end{array}$ \\
\hline $\begin{array}{l}\text { Access to } \\
\text { market }\end{array}$ & $\begin{array}{l}-0.102 \\
(-2.87) * * *\end{array}$ & $\begin{array}{l}-0.153 \\
(-3.66) * * *\end{array}$ & $\begin{array}{l}-0.105 \\
(-2.94) * * *\end{array}$ & $\begin{array}{l}-0.151 \\
(-3.62) * * *\end{array}$ & $\begin{array}{l}-0.103 \\
(-2.88) * * *\end{array}$ & $\begin{array}{l}-0.152 \\
(-3.63) * * *\end{array}$ \\
\hline Land size & $\begin{array}{l}0.001 \\
(1.63)\end{array}$ & $\begin{array}{l}0.0015 \\
(1.44)\end{array}$ & $\begin{array}{l}0.0016 \\
(2.06) * *\end{array}$ & $\begin{array}{l}0.0018 \\
(1.81)^{*}\end{array}$ & $\begin{array}{l}0.0019 \\
(2.50) * *\end{array}$ & $\begin{array}{l}0.0023 \\
(2.20) * *\end{array}$ \\
\hline $\begin{array}{l}\text { Non- } \\
\text { agricultural } \\
\text { income }\end{array}$ & $\begin{array}{l}0.394 \\
(2.40) * *\end{array}$ & $\begin{array}{l}0.534 \\
(2.76) * * *\end{array}$ & $\begin{array}{l}0.360 \\
(2.20)^{* *}\end{array}$ & $\begin{array}{l}0.502 \\
(2.61) * * *\end{array}$ & $\begin{array}{l}0.355 \\
(2.16) * *\end{array}$ & $\begin{array}{l}0.495 \\
(2.58) * * *\end{array}$ \\
\hline $\begin{array}{l}\text { Northern } \\
\text { region of } \\
\text { Bangladesh }\end{array}$ & $\begin{array}{l}-0.255 \\
(-1.26)\end{array}$ & $\begin{array}{l}-0.453 \\
(-1.83) *\end{array}$ & $\begin{array}{l}-0.276 \\
(-1.36)\end{array}$ & $\begin{array}{l}-0.472 \\
(-1.91) *\end{array}$ & $\begin{array}{l}-0.197 \\
(-0.96)\end{array}$ & $\begin{array}{l}-0.388 \\
(-1.56)\end{array}$ \\
\hline $\begin{array}{l}\text { Central region } \\
\text { of Bangladesh }\end{array}$ & $\begin{array}{l}-0.426 \\
(-2.13) * *\end{array}$ & $\begin{array}{l}-0.040 \\
(-0.17)\end{array}$ & $\begin{array}{l}-0.488 \\
(-2.44) * *\end{array}$ & $\begin{array}{l}-0.122 \\
(-0.52)\end{array}$ & $\begin{array}{l}-0.496 \\
(-2.48) * *\end{array}$ & $\begin{array}{l}-0.105 \\
(-0.45)\end{array}$ \\
\hline LR Chi-square & 96.69 & 97.95 & 93.31 & 95.95 & 97.27 & 95.31 \\
\hline Log likelihood & -401.69 & -236.01 & -403.39 & -237.01 & -401.408 & -237.33 \\
\hline
\end{tabular}

Note: Z-statistics in parentheses. ${ }^{* *}, * *$, and $*$ denote significance at the $1 \%, 5 \%$,

and $10 \%$ levels, respectively. FCS $=$ Food Consumption Score; HDDS $=$ Household Dietary Diversity Score; $\mathrm{SD}=$ standard deviation.

The results show that, in addition to the number of products, the evenness of farm production diversity is also important for food diversity. Simpson's Index implies that considering the number and evenness of different species produced increases in the level of nutrition and 
number of groups of consumed food. A possible explanation could be that households consume nutrients from their own production.

Similar to other indicators, the ADI also has a positive impact on dietary diversity. The index shows that shifting to non-rice cultivation instead of rice monoculture raises both the HDDS and FCS at a significant level. The increase in production diversification by $100 \%$ increases the probability of the HDDS to $35.54 \%$ and the FCS to $31.68 \%$, keeping other factors constant. Diversification yields benefit for dietary variety in different ways. Variety in the production of crops, animal products, fish, and other products enables households to directly consume their own diversified production. Furthermore, moving out of rice monoculture into suitable crop and non-crop agriculture is financially profitable for the farmers in Bangladesh. Diversification provides opportunities for incremental income and reduced income variability and therefore is more likely to contribute to improved food security status. Jones et al. (2014) mentioned that farmers use income earned from market-oriented production to purchase nutrient-dense foods that diversify household diets.

\section{Other influencing factors which facilitate diversified household food consumption}

A higher level of education of the household head was significantly related to household dietary diversification. The result is reasonable and was expected as higher educated household heads have greater access to nutrition, price, and weather related information through multiple sources and are in a more advantageous position to utilize available resources for their improvement compared with their less educated counterparts. In addition, educated household heads are more concerned about the nutritional aspects of foods. Gebre (2012) pointed out that educated household heads play a major role in shaping household members and facilitate better living conditions than less educated ones when considering the long-term benefits. Thus, educated households put effort into diversified food consumption.

This study found that food diversification was positively associated with the wealth status of the household at the $1 \%$ level of significance. Wealthier households with higher purchasing power are likely to consume a higher number of food items. Wealth allows farm households to invest more resources in higher return market crops and raise a larger number of livestock and fish. Wealth is also expected to act as a cushion against any decrease in income or food production. A higher level of household wealth helps to maintain consumption during unanticipated events that demand additional expenditure. This result is consistent with that reported by Parvathi (2018). 
A positive relationship between farm production and dietary diversity signifies the importance of production diversity to meet the dietary requirements of households. An increase in production per capita of non-cereal products of $100 \%$ increases the probability of varied food consumption by $4.00 \%$ ceteris paribus. Farms with more diversified production earn higher revenue and experience increased food security compared with smaller farms. Increasing demand for non-cereal food items ensures an exhilarating selling price, which in turn results in higher income for the larger diversified farms.

Better market access through reduced distance was found to improve dietary diversity. Access to market increases consumption diversification in two ways. First, greater access to market permits farms to sell various fresh agricultural products on the market at the best price. It provides the farmers with a greater opportunity to receive useful information in a timely manner. Non-cereal items such as vegetables, fruits, and dairy products are perishable and must be sold quickly on the market. Therefore, wider access to market stimulates the farmers to diversify (Rehan et al., 2017). However, Dewey (1981) mentioned that subsistence farming can no longer meet the family income needs, which leads the farmers to diversify income sources. In addition to higher income, production of non-cereal crops can more easily be incorporated into a combination of wage labor and work on the family plot than the production of subsistence crops. Second, better roads and transportation networks ensure the availability of a variety of foods for household consumption.

The effect of land size on diversification was positive and significant. Farm households with larger land size can devote larger land areas to different crop and non-crop cultivation. Using less land area for cereal production allows more diverse production. This cultivation intensity increases the production and income of households, which in turn promotes food security. This result is in line with that found in the study by Bidisha et al. (2017). The positive relationship between land size and Simpson's Index points to farms with larger land area having a greater variety of food consumption in a more balanced way than farms with smaller land area.

Similar to Jones et al. (2014), it is found that larger household size increases food diversity. Larger household size allows more family effort, especially by women who mostly remain in or immediately near to the house in developing countries. It is relatively hard for women to take part in cereal farming such as rice cultivation, but they can easily contribute to vegetable farming and non-crop farming such as poultry and livestock farming. Thus, larger household 
size facilitates the growth and consumption of various self-produced food items. It also contributes to the purchase of diversified food from the market.

Non-agricultural income had a positive and significant effect on the probability of diversity, suggesting that households with considerable income outside of agriculture prefer to supplement their dietary diversity needs through purchasing from the market. In this paper, non-agricultural income includes wage income along with income earned from non-farm activities such as the owner's non-farm enterprises. In line with the findings of this research, a previous study by Babatunde and Qaim (2010) described that non-agricultural income contributes positively to food security. Non-farm income contributes to intensive farming and higher production as a source of capital especially when it is difficult to manage financing. In addition, non-farm income can complement farm income and permits farm households to consume various food items during times of decreased farm income due to market or natural causes. Compared with the southwestern region (the reference region), rural households in the central regions showed a lower level of HDDS. However, the FCS did not demonstrate any significant result within the central regions.

\section{CONCLUSION AND POLICY RECOMMENDATIONS}

This paper specifies that agricultural diversification can be a useful strategy to improve household food diversity and therefore food security in Bangladesh. Descriptive and econometric analyses have revealed that farm diversity contributes to improving food diversification at the household level. Therefore, agricultural policy targeted to ensure food security should emphasize diversification in agricultural production. Over the years, the prime focus has been on self-sufficiency in rice production and energy availability for food security in Bangladesh (Thorne-Lyman et al., 2010) with little encouragement of farmers to diversify production. A noteworthy finding is that diversification through moving out of cereal production, especially rice cultivation, is an effective strategy to improve food diversity and thus enhance household food security status. The results showed that household size, production per capita, and land size are positively associated with household food diversity.

The study suggests that policy should stress raising the education level, development of infrastructure for better market access, and promoting non-farm income diversification along with supporting further agricultural diversification to attain household food security while highlighting the nutritional dimension. The study found that the education level of a household is a significant contributor to household food security. In order to promote access to education, 
policies that enhance household education status are vital. These policies may include increasing the number of schools in rural areas, improving teaching facilities, increasing enrollment, and more investment in education by way of public-private partnerships.

The results recognize that access to market, one of the significant factors of the study, allows farmers to receive useful information on time that benefits to buy and sell farm produce under favorable conditions. Therefore, strengthening market access through developing infrastructure or reducing travel time could improve food diversification. The findings suggest that policy geared toward increased and continuous investment in infrastructure is necessary in this regard.

\section{REFERENCES}

Ahmad, A. and Isvilanonda, S. (2003) Rural Poverty and Agricultural Diversification in Thailand, paper presented at the Second Annual Swedish school of advanced Asia and Pacific Studies, 24-26 October, Lund, Sweden.

Ashby, S. Kleve, S. McKechnie, R. and Palermo, C. (2016) Measurement of the dimensions of food insecurity in developed countries: a systematic literature review, Public Health Nutrition, Vol. 19, Issue 16, p.2887-2896.

Babatunde, R.O. and Qaim, M. (2010) Impact of off-farm income on food security and nutrition in Nigeria, Food Policy, Vol. 35, pp. 303-311.

Bamji Mahtab S. (2007) Nutrition-secure India-How do we get there? Nutrition conclave discusses the way forward, Current Science, Vol. 93, Issue. 11, pp.1473-1475

Barghouti, S., Kane, S., Sorby, K., and Ali, M. (2004) Agricultural diversification for the poor: guidelines for practitioners, Agriculture and Rural Development Department of the World Bank, Discussion Paper No. 01. Available online at: http://documents.worldbank.org/curated/en/282611468148152853/pdf/293050REPLACEM0 0Diversification0Web.pdf.

Bidisha, Sayema Haque, Khan, Akib, Imran, Khalid, Khondker, Bazlul H. and Suhrawardy, Gazi Mohammad (2017) Role of credit in food security and dietary diversity in Bangladesh, Economic Analysis and Policy, Vol. 53, March issue, pages 33-45.

Carter, S., Tagg, S. and Dimitratos, P. (2004) Beyond portfolio entrepreneurship: Multiple income sources in small firms, Entrepreneurship and Regional Development, Vol. 16, No. 6, pp. 481-499.

Cervantes-Godoy, D., Kimura, S. and Anton, J. (2013) Smallholder Risk Management in Developing Countries, OECD Food, Agriculture and Fisheries Papers, No. 61. 
Dewey, K. G. (1981) Nutritional consequences of the transformation from subsistence to commercial agriculture in Tabasco, Mexico; Human Ecology Vol: 9, No. 2, pp 151-188.

Drescher, Larissa S. and Goddard, Ellen W., (2008) Comparing Predictors of Diet Quality in Canada Over Time Under Consideration of Altering Food Guides, Staff Paper Series 52091, University of Alberta, Department of Resource Economics and Environmental Sociology.

Elhorst, J. P. (1994) Firm-Household Interrelationships on Dutch Dairy Farms, European Review of Agricultural Economics, 21, 259-276.

FAO (1996) Rome declaration on world food security and world food summit plan of action. World Food Summit 13-17 November 1996, Rome

FAO, IFAD and WFP (2015) The State of Food Insecurity in the World, Meeting the 2015 international hunger targets: taking stock of uneven progress, Food and Agriculture Organization of the United Nations, Rome.

FAO, IFAD, UNICEF, WFP and WHO (2018) The State of Food Security and Nutrition in the World 2018, Building climate resilience for food security and nutrition. Rome, FAO

Feleke, S.T., Kilmer, R. L., and Gladwin, C.H. (2005) Determinants of Household Food Security in Southern Ethiopia at the Household Level, Agricultural Economics, 33: 351-363.

Gebre, Girma Gezimu (2012) Determinants of Food Insecurity among Households in Addis Ababa City, Ethiopia, Interdisciplinary Description of Complex Systems, Vol. 10, No. 2, pp. 159-173.

General Economics Division and Planning Commission (2015). Seventh Five Year Plan FY2016-FY2020, Government of the People's Republic of Bangladesh, Available online at:

http://plancomm.portal.gov.bd/sites/default/files/files/plancomm.portal.gov.bd/files/aee61c03 _3c11_4e89_9f30_d79639595c67/7th_FYP_18_02_2016.pdf (accessed on 09 September 2019).

Greene, William H. (2012) Econometric Analysis (7th Edition), Upper Saddle River N J, Prentice Hall.

Hansson, H. Ferguson, R. and Olofsson, C. (2010) Understanding the diversification and specialization of farm businesses, Agricultural and Food Science, 19, 269-283.

Hoddinott, John \& Yohannes, Yisehac, (2002) Dietary diversity as a food security indicator, FCND discussion papers 136, International Food Policy Research Institute (IFPRI). 
Islam, Abu Hayat Md. Saiful; von Braun, Joachim; Thorne-Lyman, Andrew L.; and Ahmed, Akhter, U. 2018, (2018) Farm diversification and food and nutrition security in Bangladesh: empirical evidence from nationally representative household panel data, Food Security, Vol: 10, pp: 701-720

Jones AD (2017). Critical review of the emerging research evidence on agricultural biodiversity, diet diversity, and nutritional status in low- and middle-income countries. Nutrition Reviews 1-14, Vol. 75, No. 10, pp. 769-782

Jones, A. D., Shrinivas, A. and Bezner-Kerr R. (2014) Farm production diversity is associated with greater household dietary diversity in Malawi: Findings from nationality representative data, Food Policy, Vol. 46, pp. 1-12.

Joshi, P.K., Gulati, A. and Cummings, R. (2007) Agricultural Diversification in South Asia: Beyond Food Security, In: P.K. Joshi, Ashok Gulati, and Ralph Cummings (eds): Agricultural diversification and smallholders in South Asia, Academic Foundation, India.

Kant AK (2004), Dietary patterns and health outcomes, Journal of the American Dietetic Association; Vol. 104, No. 4, pp. 615-35.

Kennedy, Gina; Ballard, Terri; and Marie Claude Dop (2011) Guidelines for Measuring Household and Individual Dietary Diversity, Rome, Food and Agriculture Organization of the United Nations.

Kirsten, Johann ; Townsend, Robert and Gibson, Chris ( 1998) Determining the contribution of agricultural production to household nutritional status in KwaZulu-Natal, South Africa, Development Southern Africa, Vol. 15, No 4, pp. 573-587.

Koppmair, Stefan; Kassie, Menale and Qaim, Matin (2017) Farm production, market access and dietary diversity in Malawi. Public Health Nutrition, Vol 20, No. 2, 325-335. http://dx.doi.org/10.1017/ S1368980016002135

Meert, H., Huylenbroeck, G.V., Vernimmen, T., Bourgeois, M. and Hecke, E.V. (2005) Farm household survival strategies and diversification on marginal farms, Journal of Rural Studies, Vol.21, pp. 81-97.

Miah, M.A.M. and Haque, A.K.E. (2013) Policy Options for Supporting Agricultural Diversification in Bangladesh, report presented at the workshop on Research to Inform Food and Nutrition Security Policies, 3-4 July, Dhaka.

Minot, N., Epprecht, M., Anh, T. T. T. and Trung, L. Q. (2006) Income diversification and poverty in the Northern uplands of Vietnam, International Food Policy Research Institute Research Report, No. 145, Washington, DC. Available online at: http://www.ifpri.org/sites/default/files/publications/rr145.pdf (accessed on 25 May 2019). 
Mishra, A.K., El-Osta, H.S. and Sandretto, C.L. (2004) Factors Affecting Farm Enterprise Diversification, Agricultural Finance Review, Vol 64, No. 2, pp. 151 - 166.

Parvathi, Priyanka (2018) Does mixed crop-livestock farming lead to less diversified diets among smallholders? Evidence from Laos. Agricultural Economics, Vol. 49 , Issue 4, pp. 497-509.

Pingali, P. (2015) Agricultural policy and nutrition outcomes - getting beyond the preoccupation with staple grains, Food Security, Vol: 7, pp: 583-591-, Available online at: : https://doi.org/10.1007/s12571-015-0461-X

Rahman, S. (2015) Micro-determinants of income Inequality and consumption in rural Bangladesh, Journal of Poverty Alleviation and International Development, Vol 6, No 2. pp 107-134.

Rajendran, S., Afari-Sefa, V., Shee . A, Bekunda, M., Dominick, I., Lukumay, P.J., (2017) Does crop diversity contribute to dietary diversity? Evidence from integration of vegetables into maize farming systems in Tanzania, Agriculture \& Food Security, DOI 10.1186/s40066-017-0127-3, Available online at :

https://agricultureandfoodsecurity.biomedcentral.com/track/pdf/10.1186/s40066-017-0127-3

Rashid, D. A., Smith, L. C., \& Rahman, T. (2011) Determinants of dietary quality: Evidence from Bangladesh. World Development, Vol. 39, No.12, pp. 22212231. https://doi.org/10.1016/j.worlddev.2011.05.022

Rehan, S.F., Sumelius, J. and Bäckman, S. (2017) Determinants of on-farm diversification in Bangladesh, International Journal of Agricultural Resources, Governance and Ecology, Vol. 13, No. 3, pp. 294-313.

Rønning, L. and Kolvereid, L. (2006) Income diversification in Norwegian farm households: Reassessing pluriactivity, International Small Business Journal, Vol. 24, No.4, pp. 405-420.

Ruel MT (2003) Is dietary diversity an indicator of food security or dietary quality? A review of measurement issues and research needs, Food and Nutrition Bulletin, Vol. 24, No.2 Sen, A., (1981) Poverty and Famines: An Essay on Entitlement and Deprivation, Clarendon Press, Oxford.

Sibhatu, K.T., Krishna, V.V. and Qaim, M. (2015) Production diversity and dietary diversity in smallholder farm households, Proceedings of the National Academy of Sciences USA (PNAS) 112, pp. 10657-10662, Available online at: 
Singh, I., Squire, L., Strauss, J. (Eds.), (1986) Agricultural Household Models: Extensions, Applications, and Policy. Johns Hopkins University Press, Baltimore.

Swindale, Anne and Punam Ohri-Vachaspati (2005) Measuring Household Food Consumption: A Technical Guide. Washington, D.C.: Food and Nutrition Technical Assistance (FANTA) Project, Academy for Educational Development (AED).

Thorne-Lyman, A., Valpiani, N., Sun, K., Semba, R. D., Klotz, C. L., Kraemer, K., ... Bloem, M. (2010) Household dietary diversity and food expenditures are closely linked in rural Bangladesh, increasing the risk of malnutrition due to the financial crisis, Journal of Nutrition, Vol. 140, No. 1.

Van den Berg, M.M., Hengsdijk, H., Wolf, J., Van Ittersum, M.K., Guanghuo, W and Roetter, R.P. (2007) The impact of increasing farm size and mechanization on rural income and rice production in Zhejiang province, Agricultural Systems, Vol.94, pp. 841-850.

Warr, P. (2014) Food insecurity and its determinants, Australian Journal of Agricultural and Resource Economics, 58, pp. 519-537.

Weinberger, K. and Lumpkin, T. A. (2007) Diversification into Horticulture and Poverty Reduction: A Research Agenda, World Development, Vol. 35, No. 8, pp. 1464-1480.

WFP (World Food Programme) (2009) Food Consumption Score (FCS) in Bangladesh Context, Technical Guideline, Rome, Italy.

Yu, X., Abler, D. (2009) The demand for food quality in rural China, American Journal of Agricultural Economics, Vol. 91, pp. 57-69

Zhou, De ; Yu, Xiaohua ; Abler, David ; Chen, Danhong, (2014) Projecting Meat and Cereals Demand for China Based on a Meta-Analysis of Income Elasticities, Global Food Discussion Papers 168528, Georg-August-University of Göttingen, Department of Agricultural Economics and Rural Development. 